\title{
Real-time surrogate analysis for potential oil and gas contamination of drinking water resources
}

\author{
Ji-Hee Son • Kenneth H. Carlson
}

Received: 4 December 2013/Accepted: 15 April 2014/Published online: 1 May 2014

(C) The Author(s) 2014. This article is published with open access at Springerlink.com

\begin{abstract}
Public concerns related to the fast-growing shale oil and gas industry have increased during recent years. The major concern regarding shale gas production is the potential of fracturing fluids being injected into the well or produced fluids flowing out of the well to contaminate drinking water resources such as surface water and groundwater. Fracturing fluids contain high total dissolved solids (TDS); thus, changes in TDS concentrations in groundwater might indicate influences of fracturing fluids. An increase of methane concentrations in groundwater could also potentially be due to hydraulic fracturing activities. To understand the possible contamination of groundwater by fracturing activities, real-time groundwater monitoring is being implemented in the Denver-Julesburg basin of northeast Colorado. A strategy of monitoring of surrogate parameters was chosen instead of measuring potential contaminants directly, an approach that is not cost effective or operationally practical. Contaminant surrogates of TDS and dissolved methane were proposed in this study, and were tested for correlation and data distribution with laboratory experiments. Correlations between TDS and electrical conductivity (EC), and between methane contamination and oxidation-reduction potential (ORP) were strong at low concentrations of contaminants ( $1 \mathrm{mg} / \mathrm{L}$ TDS and $0.3 \mathrm{mg} / \mathrm{L} \mathrm{CH}_{4}$ ). Dissolved oxygen (DO) was only an effective surrogate at higher methane concentrations $(\geq 2.5 \mathrm{mg} / \mathrm{L})$. The results indicated that EC and ORP are effective surrogates for detecting concentration changes of
\end{abstract}

J.-H. Son $(\bowtie) \cdot$ K. H. Carlson

Department of Civil and Environmental Engineering,

Colorado State University, Fort Collins, CO 80523, USA

e-mail: jie.son@colostate.edu

K. H. Carlson

e-mail: kcarlson@engr.colostate.edu
TDS and methane, respectively, and that a strategy of monitoring for easy to measure parameters can be effective detecting real-time, anomalous behavior relative to a predetermined baseline.

Keywords Electrical conductivity · Fracturing fluids . Methane $\cdot$ Oxidation-reduction potential $\cdot$ Surrogate $\cdot$ Total dissolved solids

\section{Introduction}

Natural gas has rapidly developed in recent years as an emerging and renewable clean energy source that can replace coal. Since 2008, shale gas extraction activities have grown exponentially due to the development of economically feasible and advanced horizontal drilling techniques, accounting for $30 \%$ of the United States' natural gas production in 2011. It is expected to be nearly half (49\%) of total gas production by 2035 (USEIA 2012; Vengosh et al. 2013).

Natural gas generates lower levels of particulates, sulfur dioxide, mercury, and other pollutants, and reduces up to $45 \%$ of carbon dioxide per unit of energy compared to coal (Kharaka et al. 2013). However, new drilling and fracturing technologies used for shale gas production have raised environmental concerns related to air and water quality, including methane migration, contaminant transport, water use, wastewater discharge, and surface spills (Vidic et al. 2013).

One of the major concerns regarding shale gas extraction activities is the potential contamination of drinking water resources, such as groundwater and surface water, through poorly constructed well casings, accidental surface spills or methane migration from the production zone to the 
aquifer. Fracturing fluids are a critical component of the stimulation and completion practices, and contain organic and inorganic chemicals such as potassium carbonate, sodium chloride, citric acid, guar gum, ethylene glycol, sodium carbonate, borate salts, acid, petroleum distillate, and isopropanol (Rahm 2011). Therefore, the fluids usually have high total dissolved solids (TDS) - up to $300,000 \mathrm{mg} /$ $\mathrm{L}$ of mainly chloride and sodium, followed by calcium, magnesium, potassium, sulfate, barium, strontium, and bromide (Neff et al. 2011).

One of the key issues associated with fracturing practices is methane gas migration and its origins (Gorody et al. 2005; Osborn et al. 2011; Molofosky et al. 2011, 2013). Methane is colorless, odorless, tasteless, and not a health hazard when inhaled and digested, but it is explosive and flammable when methane concentration in water is greater than the solubility of methane in water, $28-30 \mathrm{mg} / \mathrm{L}$, or when methane in air exceeds the lower explosive limit (LEL), $5 \%$ by volume in air (USGS 2006, 2012). Concentrations of methane between 10 and $28 \mathrm{mg} / \mathrm{L}$ ( 3 and $5 \%$ by volume in air) can also be dangerous because methane concentrations might increase to explosive levels (Eltschlager et al. 2001).

Methane originates from two different mechanisms: biogenic methane generation from microbial decomposition of organic matter at a relatively shallow depth; and thermogenic, which produces methane at depths of greater than 1,000 $\mathrm{m}$ under high temperature and pressure. There is a substantial debate on possible increase in thermogenic methane due to the creation of connectivity between deep and shallow formations (Floodgate and Judd 1992; Vengosh et al. 2013).

The Colorado Oil and Gas Conservation Commission recently implemented Rule 609 that requires groundwater monitoring before and after drilling, using the periodic grab sampling methods followed by laboratory analysis. The current sampling and lab analysis for TDS and methane measurements requires labor and time, and the results provide only a snapshot in time. Real-time groundwater monitoring was suggested as means of filling the gap in the data between periodic sampling events. A project was initiated in the Denver-Julesburg basin of northeast Colorado to install real-time, continuous monitoring of groundwater in close proximity to existing and future oil and gas activity. Measurements of actual potential contaminant streams (produced fluids and methane) were considered infeasible due to cost and operational considerations. Instead, a strategy of monitoring contaminant surrogate parameters was being pursued.

Based on the well-known relationship of TDS to electrical conductivity (EC) and a study by Atekwana et al. (2004), which showed a strong correlation between TDS and EC in an aquifer contaminated with hydrocarbons, this study proposed EC as a surrogate for elevated TDS that would be expected if produced fluids contaminate low-TDS fresh water. TDS contamination itself is not of concern but this would be an indication of produced fluid intrusion into the aquifer, including potentially hazardous compounds associated with it. Previous studies have shown positive results for oxidation-reduction potential (ORP) as a surrogate for dissolved methane in groundwater. This result was likely explained as the $\mathrm{CO}_{2}-\mathrm{CH}_{4}$ couple beginning to dominate solution redox conditions. Recent studies have shown strong correlations when methane concentrations are $>5 \mu \mathrm{g} / \mathrm{L}$ (Darling and Gooddy 2006; Ioka et al. 2011).

The research described in this paper was designed to assess the relationships between produced water and the correspondingly high TDS and the proposed surrogate, EC. In addition, potential dissolved methane surrogates ORP and DO were studied for applicability to the real-time monitoring system.

\section{Methods}

Experimental design

Bench scale experiments were designed to test correlations between TDS in produced water and EC, between methane and ORP, and between methane and DO at the laboratory scale (Fig. 1).

Surface water from Horsetooth Reservoir, located next to the laboratory at the Engineering Research Center (ERC) of Colorado State University in Fort Collins, USA, was used for the experiments.

For the TDS surrogate experiment, two continuous flow experiments were performed. Produced water (PW) was collected from two active oil and gas wells in Weld County, CO, and concentrations of TDS in the PWs were measured using USEPA method 160.1 (USEPA 1979). TDS concentrations of the two PWs, PW 1 and PW 2, were 25,500 and $34,400 \mathrm{mg} / \mathrm{L}$, respectively, mainly from chloride (56-60\%) and sodium (36-38\%) (Table 1).

With surface water, the two collected PWs flowed through the system of each experiment at a constant flow rate of $0.15 \mathrm{~mL} / \mathrm{min}$ for $2 \mathrm{~h}$, using a peristaltic pump with flow capabilities between 0.06 and $580 \mathrm{~mL} / \mathrm{min}$ (Masterflex Cole-Parmer, USA).

PW and surface water inflow was mixed using a propeller mixer in the 16-L reactor at room temperature. Outflow EC was automatically measured by a real-time EC sensor, OTT ecoLog 800 (OTT Hydromet, Germany), and the data were saved every minute during the tests. Outflow water samples were collected in $40 \mathrm{~mL}$ serum bottles every $5 \mathrm{~min}$ for the first $10 \mathrm{~min}$ then every $10 \mathrm{~min}$, cooled to $4{ }^{\circ} \mathrm{C}$, and analyzed within 7 days. 
Fig. 1 Experimental designs of the total dissolved solid (TDS) surrogate test (a) and the methane surrogate test (b)

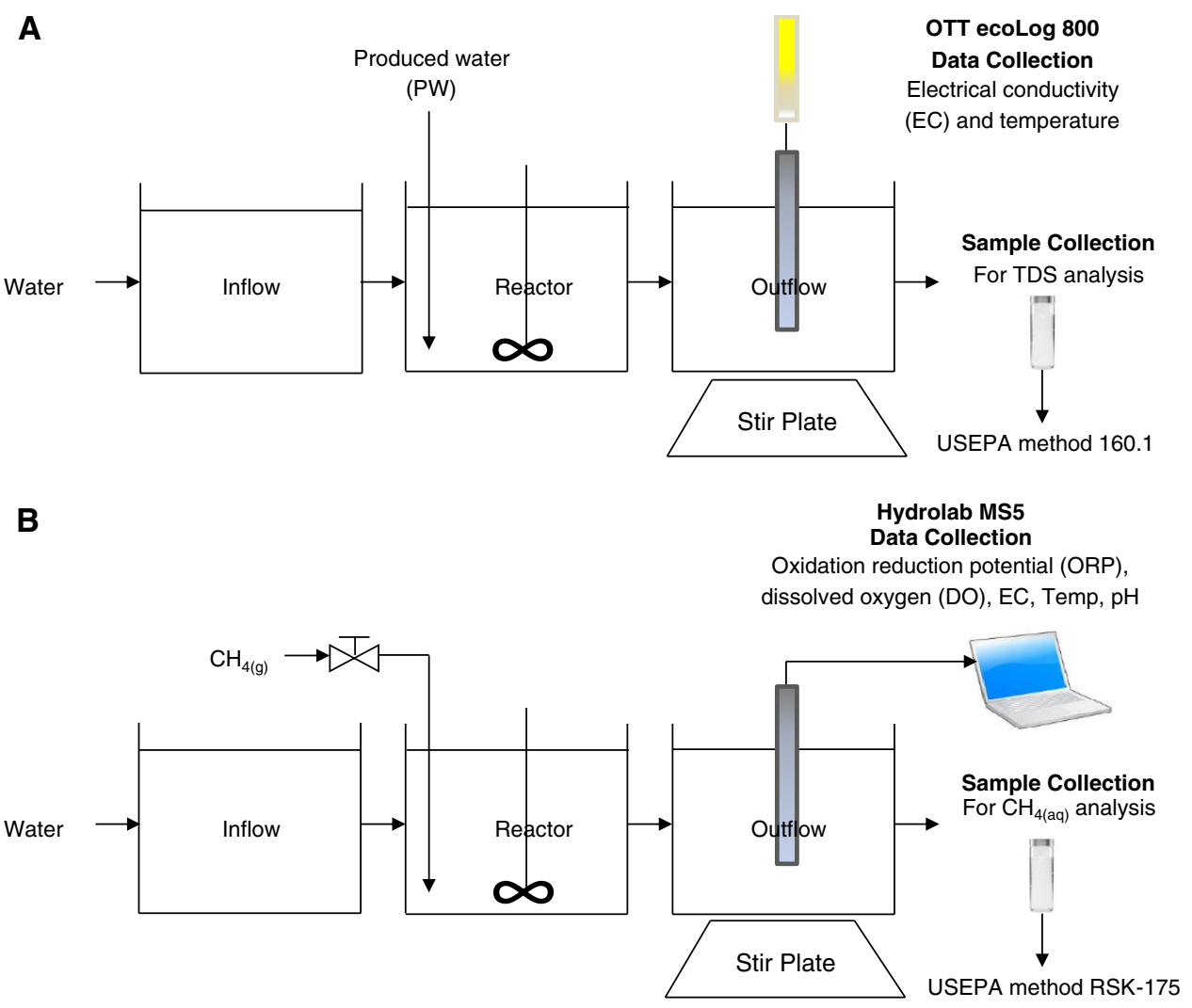

Table 1 Composition of produced water (PW) used as a contamination source of total dissolved solids (TDS)

\begin{tabular}{lll}
\hline Variable & Concentration $(\mathrm{mg} / \mathrm{L})$ & \\
\cline { 2 - 3 } & PW 1 & PW 2 \\
\hline $\mathrm{TDS}$ & $34,358.7$ & $25,457.4$ \\
$\mathrm{Cl}$ & 20,647 & 14,340 \\
$\mathrm{Na}$ & 12,549 & 9,676 \\
$\mathrm{HCO}_{3}$ & 391 & 589 \\
$\mathrm{Ca}$ & 294 & 282 \\
$\mathrm{Fe}$ & 160 & 154 \\
$\mathrm{~K}$ & 163 & 272 \\
$\mathrm{Sr}$ & 51.4 & 44.4 \\
$\mathrm{Mg}$ & 48.8 & 45.7 \\
$\mathrm{Ba}$ & 30.5 & 23.1 \\
$\mathrm{~B}$ & 20.4 & 21 \\
$\mathrm{Mn}$ & 1.9 & - \\
$\mathrm{Al}$ & 1.1 & 0.4 \\
$\mathrm{Cu}$ & 0.5 & - \\
$\mathrm{SO}_{4}$ & 0.05 & 9.8 \\
\hline
\end{tabular}

The experimental set-up for the methane surrogate test consists of methane gas (99.9\%), surface water, a 16-L reactor, and multi-detection real-time sensors. Methane gas $(99.9 \%)$ was saturated using a gas diffuser (Corning, Tewksbury, USA) by bubbling at a gas flow rate of $24 \mathrm{~mL} /$ min, which is the lowest gas flow that can be achieved by a commercially available gas flow meter. For $12-28 \mathrm{~h}$, the methane was allowed to saturate in the 16- $\mathrm{L}$ continuousstirred reactor in continuously flowing water at room temperature and atmospheric pressure. Once the surrogates were stabilized or the range of data fluctuation was assumed at steady or near steady state, the test was stopped.

Different water flow rates $(300,500,580$, and $2,300 \mathrm{~mL} / \mathrm{min}$ ) were used to adjust reactor methane concentrations using two automatic peristaltic pumps. Each pump had different flow capacities: $0.06-580 \mathrm{~mL} / \mathrm{min}$ and 0.06-2,300 mL/min (Masterflex Cole-Parmer, USA).

Outflow water quality parameters, including ORP, EC, $\mathrm{DO}$ and $\mathrm{pH}$, were measured in real time with water temperature using a multi-sensor probe, Hydrolab MS5 (Hach Hydromet, USA), and the data were saved every minute. For further methane analysis, outflow samples at near steady state were carefully collected and completely filled in $20-\mathrm{mL}$ serum bottles, so as not to create bubbles. Samples to be analyzed for methane were kept at $4{ }^{\circ} \mathrm{C}$ and analyzed within 14 days.

Background tests and sample analysis

Background tests were conducted for 3 days prior to each experiment to stabilize the sensors under the same condition as described above, with the exception of contaminants 
such as PW and methane. Water quality parameters, such as ORP, EC and $\mathrm{pH}$, collected at the background tests were compared with the results from the experiments.

Collected outflow samples from the TDS surrogate tests were transferred in a cooler to the USEPA approved laboratory, and TDS were measured using USEPA method 160.1 (USEPA 1979). Methane concentrations in the outflow of the methane surrogate tests were analyzed using a gas chromatography flame ionization detection (GC-FID) method (USEPA method RSK-175), which has a detection limit of $10 \mu \mathrm{g} / \mathrm{L}$ (USEPA 2004).

Data analysis

Water quality data collected for an hour immediately before each experiment were used as background data. The background data and the experimental data were compared, and differences between the datasets were tested for significance using multivariate analysis at the 0.001 significance level. All statistical data analysis was performed using SPSS v.20 (IBM Corp., USA). Multivariate correlation and covariance test and a general linear regression model were used to evaluate relationships between contaminants: TDS and methane, and tested surrogates.

A period of steady state during the methane surrogate experiments was reevaluated by linear regression and statistical analysis methods suggested by Yum and Peirce (1997), then distributions of two datasets, background data and steady state data, were compared to investigate possible surrogates that could detect shifts of methane concentrations in water.

\section{Results and discussion}

EC as a surrogate for PW/TDS contamination

In the first continuous flow test of the TDS surrogate experiment (Fig. 2a), where PW 1 was used as a contaminating source of TDS, the mean EC of the background test conducted prior to the experiment was $81.8 \mu \mathrm{S} /$ $\mathrm{cm}$ with a standard deviation of 0.39 at water temperature of $22.5 \pm 0.13{ }^{\circ} \mathrm{C}$. Both at the beginning of the experiment and immediately after it, the PW contained high concentrations of TDS $(34,400 \mathrm{mg} / \mathrm{L})$ and was flowing into the system at a low flow rate of $0.15 \mathrm{~mL} / \mathrm{min}$. In less than a minute EC increased to $84 \mu \mathrm{S} / \mathrm{cm}$, which is three times as much as the standard deviation of the background mean and is out of range of the background data distribution.

The second experiment used PW 2 (Fig. 2b), whose TDS concentration of $25,500 \mathrm{mg} / \mathrm{L}$ is lower than PW 1 . During this second experiment, EC was raised to $88 \mu \mathrm{S} / \mathrm{cm}$ after $5 \mathrm{~min}$, which is above the range of background $\mathrm{EC}$ $(\mu=85.57 \mu \mathrm{S} / \mathrm{cm} ; \sigma=0.52)$.

The EC value then gradually increased by time during both the first and second TDS surrogate experiments and reached 204 and $131 \mu \mathrm{S} / \mathrm{cm}$, respectively, within $2 \mathrm{~h}$.

In order to avoid temperature effects on EC, water temperature during the tests was maintained either within the range of the background test's water temperature or below the mean background water temperature (Hayashi 2004).

Concentrations of TDS in samples collected after $5 \mathrm{~min}$ of the first and second tests increased to $89 \mathrm{mg} / \mathrm{L}$ from 82 and to $27 \mathrm{mg} / \mathrm{L}$ from $26 \mathrm{mg} / \mathrm{L}$, and further increased to 200 and $59 \mathrm{mg} / \mathrm{L}$, respectively, at the end of the tests.

Strong correlations between TDS and EC were obtained from both experiments. The $R^{2}$ values of a linear regression model of the data from two experiments were 1 and 0.99 for both relationships between TDS and EC, and between TDS and percent volume of PW in outflow.

From the detection limit estimation method suggested by the American Chemical Society (MacDougall et al. 1980) and the Royal Society of Chemistry (Analytical Methods Committee of Royal Society Chemistry 1987), it was found that only $0.001-0.006 \%$ of the PWs used for the
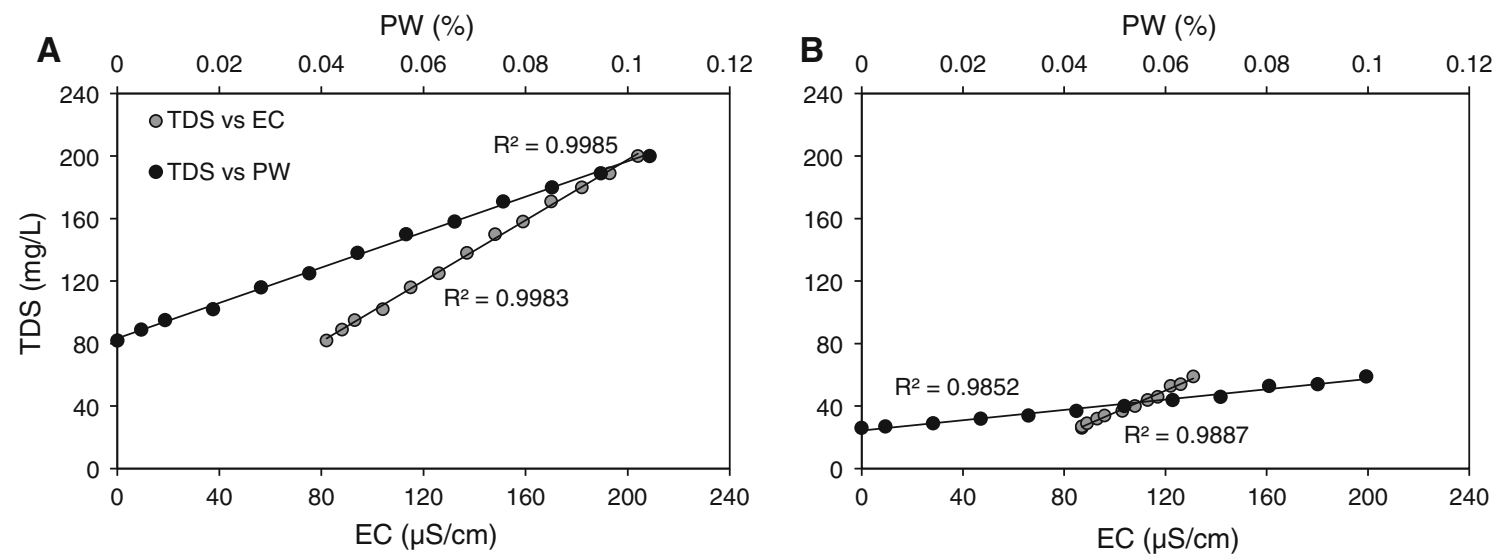

Fig. 2 Relationships of TDS to EC and PWs: PW 1 (a) and PW 2 (b) at water temperature of $21.4 \pm 0.01{ }^{\circ} \mathrm{C}$ 
experiments, or $<1 \mathrm{mg} / \mathrm{L}$ of changes in TDS concentrations in water can be detected by EC.

The TDS concentrations of PW1 and PW2 that were used for this study were in the range of typical PW TDS concentration $(5,000-300,000,000 \mathrm{mg} / \mathrm{L})$, but the concentrations were much lower than mean TDS concentration of typical PW (Table 1). Concentrations of the most abundant ions, chloride and sodium, in PW1 and PW2 were less than typical ranges of mean concentrations of chloride $(46,100-141,000 \mathrm{mg} / \mathrm{L})$ and sodium $(23,000-57,300 \mathrm{mg} /$ L) (Neff et al. 2011). Therefore, the typical PW having higher TDS concentration would show even lower detection limits than the detection limit that was found in this study.

\section{Methane surrogates}

The dissolved methane concentrations started at a low water flow rate of $300 \mathrm{~mL} / \mathrm{min}$, and after $11 \mathrm{~h}$ of methane gas contact with flowing water it reached an average $(\mu)$ of $6.04 \mathrm{mg} / \mathrm{L}$. At that point there was a standard error (SE) of 0.14 , which had the maximum dissolved methane concentrations of $6.24 \mathrm{mg} / \mathrm{L}$. ORP and DO logarithmically decreased as dissolved methane concentrations increased during the first $11 \mathrm{~h}$, and then stabilized and reached a near steady state.

Dissolved methane concentrations from collected outflow samples and the possible surrogates ORP and DO, when measured at the same time that outflow samples were collected, appeared to be negatively correlated. Correlations were significant, at $r=-0.896$ and $r=-0.917$, respectively, at the significance level of 0.01 using multivariate correlation analysis based on Pearson's correlation coefficient (Table 2). Conductivity $(74.61 \pm 0.014 \mu \mathrm{S} / \mathrm{cm})$ had weak correlations with dissolved methane concentrations, but $\mathrm{pH}(7.67 \pm 0.002)$ showed a positive strong correlation $(r=0.588)$ at a significance level of 0.05 in Experiment 1.

The average of ORP data during background conditions was $328.5 \mathrm{mV}$ with the standard deviation of $0.5(n=60)$ and the range of $326.7-330.5 \mathrm{mV}$, and the average ORP data during steady state were $323.8 \mathrm{mV}$ with the standard deviation of $0.39 \quad(n=672)$ and the range of 322.3-325.4 mV. Distributions of two groups of ORP data did not overlap each other and therefore it was significantly different $(p<0.0001)$.

Distribution of DO data during background condition had the average of $4.86 \mathrm{mg} / \mathrm{L}$ with low standard deviation at $0.06(n=60)$ and the range of $4.66-5.12 \mathrm{mg} / \mathrm{L}$ while the DO average during steady state was $3.65 \mathrm{mg} / \mathrm{L}$ and the standard deviation was $0.1(n=672)$ with the range of $3.23-4.07 \mathrm{mg} / \mathrm{L}$. DO data distributions of background conditions and of steady state were separate and significantly different, as in the ORP results in Experiment 1.

From these results, both ORP and DO have shown the ability to detect shifts in methane concentrations in water, when the saturated dissolved methane concentrations are $6.04 \pm 0.14 \mathrm{mg} / \mathrm{L}$.

In Experiment 2, dissolved methane concentrations increased logarithmically and reached a steady state within $18 \mathrm{~h}$, while ORP and DO decreased logarithmically. Dissolved methane concentrations at a steady state were $4.6 \pm 0.16 \mathrm{mg} / \mathrm{L}(\mu \pm \mathrm{SE})$ with the continuous inflow water rate at $500 \mathrm{~mL} / \mathrm{min}$.

Table 2 Range of tested parameters: Oxidation reduction potential (ORP), dissolved oxygen (DO), temperature, pH, and electrical conductivity (EC) during experiments and correlation coefficient (r) between dissolved methane concentrations and parameters

\begin{tabular}{|c|c|c|c|c|c|}
\hline \multirow{3}{*}{$\begin{array}{l}\text { Experiment no. } \\
\text { (Sample size) }\end{array}$} & \multirow{3}{*}{$\begin{array}{l}\text { Dissolved methane } \\
\text { concentration }(\mathrm{mg} / \mathrm{L})\end{array}$} & \multicolumn{4}{|c|}{ Parameter (correlation) } \\
\hline & & \multicolumn{4}{|c|}{ Suggested surrogate } \\
\hline & & ORP (mV) & DO $(\mathrm{mg} / \mathrm{L})$ & $\mathrm{pH}$ & $\mathrm{EC}(\mu \mathrm{S} / \mathrm{cm})$ \\
\hline $1(\mathrm{n}=17)$ & $0-6.24$ & $\begin{array}{l}322.3-330.5 \\
\left(-0.896^{\mathrm{b}}\right)\end{array}$ & $\begin{array}{l}3.23-5.12 \\
\left(-0.917^{\mathrm{b}}\right)\end{array}$ & $\begin{array}{l}7.61-7.70 \\
\left(0.588^{\mathrm{a}}\right)\end{array}$ & $\begin{array}{l}74-75 \\
(0.362)\end{array}$ \\
\hline $2(\mathrm{n}=16)$ & $0-4.73$ & $\begin{array}{l}264.8-280.6 \\
\left(-0.951^{b}\right)\end{array}$ & $\begin{array}{l}2.70-4.77 \\
\left(-0.983^{b}\right)\end{array}$ & $\begin{array}{l}7.43-7.65 \\
\left(0.756^{\mathrm{b}}\right)\end{array}$ & $\begin{array}{l}69-75 \\
(-0.374)\end{array}$ \\
\hline $3(\mathrm{n}=13)$ & $0-2.65$ & $\begin{array}{l}268.0-279.8 \\
\left(-0.963^{b}\right)\end{array}$ & $\begin{array}{l}3.10-4.82 \\
\left(-0.974^{b}\right)\end{array}$ & $\begin{array}{l}7.42-7.63 \\
\left(0.779^{\mathrm{b}}\right)\end{array}$ & $\begin{array}{l}74-75 \\
\left(0.570^{\mathrm{a}}\right)\end{array}$ \\
\hline $4(\mathrm{n}=13)$ & $0-0.95$ & $\begin{array}{l}324.6-379.0 \\
\left(-0.769^{b}\right)\end{array}$ & $\begin{array}{l}6.20-6.71 \\
(-0.181)\end{array}$ & $\begin{array}{l}6.80-7.03 \\
\left(-0.741^{\mathrm{b}}\right)\end{array}$ & $\begin{array}{l}68-72 \\
(-0.191)\end{array}$ \\
\hline $5(\mathrm{n}=17)$ & $0-0.55$ & $\begin{array}{l}296.5-335.0 \\
\left(-0.700^{\mathrm{b}}\right)\end{array}$ & $\begin{array}{l}5.55-6.30 \\
(-0.372)\end{array}$ & $\begin{array}{l}6.50-6.72 \\
(-0.080)\end{array}$ & $\begin{array}{l}64-71 \\
(0.226)\end{array}$ \\
\hline
\end{tabular}

${ }^{a}$ Correlation is significant at the 0.05 level

${ }^{\mathrm{b}}$ Correlation is significant at the 0.01 level 
Strong negative correlations with dissolved methane concentrations from samples collected at the outflow stage of the experiment were found at ORP $(r=-0.951)$ and DO $(r=-0.983)$, and a strong positive correlation ( $r=0.756)$ was found in $\mathrm{pH}(7.59 \pm 0.002)$ at a significance level of 0.01 (Table 2). At a steady state, the average ORP data was $266.1 \mathrm{mV}$ and the standard deviation was $0.34(n=450)$ and the range of $264.8-267.5 \mathrm{mV}$. Background ORP data collected prior to Experiment 2 had an average of $278.6 \mathrm{mV}$ with a standard deviation of 0.5 $(n=60)$ and the range of $276.6-280.6 \mathrm{mV}$.

Background DO data distribution was narrow with the standard deviation of 0.01 and the average of $4.74 \mathrm{mg} / \mathrm{L}$ ( $n=60$ ) with the range of $4.70-4.77 \mathrm{mg} / \mathrm{L}$, and steady state DO data had an average of $3.04 \mathrm{mg} / \mathrm{L}$ and a standard deviation of $0.09 \quad(n=450)$ with the range of 2.70-3.39 mg/L. Both ORP and DO data at steady state were statistically different from the background or control conditions $(p<0.0001)$.

Dissolved methane concentrations at a steady state reached $2.5 \pm 0.33 \mathrm{mg} / \mathrm{L}$ ( $\mu \pm$ S.E.) in Experiment 3 after $7 \mathrm{~h}$ of experiments with the maximum concentration of $2.65 \mathrm{mg} / \mathrm{L}$. Correlations of methane with ORP and DO were strong at $r=-0.963$ and $r=-0.973$, respectively, and $\mathrm{pH}$ level also had a strong correlation with methane at $r=-0.779$, with the average $\mathrm{pH}$ of $7.52 \pm 0.003$ $(\mu \pm \mathrm{SE})$ at the significance level of 0.01 (Table 2). EC showed a strong positive correlation $(r=0.57)$ at the significance level of 0.05 . ORP and DO had averages of $270.9 \mathrm{mV}$ and $3.89 \mathrm{mg} / \mathrm{L}$, respectively, at a steady state with standard deviations of 0.73 and 0.20 , respectively $(n=480)$, and the range of $268.0-273.8 \mathrm{mV}$ and $3.10-4.67 \mathrm{mg} / \mathrm{L}$, respectively.

Average backgrounds of ORP and DO were $279 \mathrm{mV}$ and $4.74 \mathrm{mg} / \mathrm{L}$, respectively, with standard deviations of 0.73 and 0.20 , respectively $(n=60)$, and the range of 278.2-279.8 $\mathrm{mV}$ and 4.66-4.82 $\mathrm{mg} / \mathrm{L}$, respectively. Distributions of both ORP and DO at a steady state and in background conditions do not overlap and are statistically different ( $p<0.0001$ ), but DO data distributions of the two groups, background conditions and steady state, are closer than previous experiments.

Water flow rate was further increased to $2,300 \mathrm{~mL} / \mathrm{min}$ to reduce dissolved methane concentrations at a steady state with a fixed gas flow rate of $24 \mathrm{~mL} / \mathrm{min}$ in Experiment 4 . Steady state conditions were achieved in $2 \mathrm{~h}$, and the average dissolved methane concentration was $0.69 \mathrm{mg} /$ $\mathrm{L}$ with the standard error of 0.04 .

Unlike the previous experiments, correlation between methane and DO was not strong $(r=-0.181)$, but ORP $(r=-0.769)$ and $\mathrm{pH}(r=-0.741)$ showed strong correlations with methane at a significance level of 0.01 (Table 2), where $\mathrm{pH}$ was $6.8 \pm 0.015$, during the experiment. ORP averages at steady state $(n=782)$ and in background conditions $(n=60)$ were 344.8 and $374.7 \mathrm{mV}$, respectively, with standard deviations of 5.06 and 1.09, respectively, and the range of $324.6-365.1 \mathrm{mV}$ and $6.20-7.18 \mathrm{mg} / \mathrm{L}$, respectively.

Distributions of ORP data at steady state and in background conditions were separate and significantly different $(p<0.0001)$. However, distributions of DO at a steady state and in background conditions, which had averages of 6.69 and $6.64 \mathrm{mg} / \mathrm{L}$, respectively, and standard deviations of 0.12 and 0.02 , respectively, and the range of 370.3-379.0 $\mathrm{mV}$ and 6.57-6.71 $\mathrm{mg} / \mathrm{L}$, respectively, overlapped. Using multivariate analysis based on MANOVA, two groups of DO data were also statistically different at the significant level of 0.0001 , but Linacre (1996) reported that any difference between means will be statistically significant when samples are large, and recommended discovering how much the distributions overlap, although statistical analysis found significance between the distributions. Therefore, it is difficult to conclude that DO is able to detect methane concentrations changes from background conditions when saturated methane concentrations are $0.69 \pm 0.04 \mathrm{mg} / \mathrm{L}$.

Dissolved methane concentrations reached $0.30 \pm 0.03 \mathrm{mg} / \mathrm{L}(\mu \pm \mathrm{SE})$ after $2 \mathrm{~h}$ in Experiment 5 using the same water and gas flow rates as Experiment 4. Although the experiment did not reach a steady state, according to the linear regression analysis for evaluating steady state conditions (Yum and Peirce 1997), ORP and DO decreased from background conditions and ORP fluctuated with a standard deviation of 4.19 with an average of $313.3 \mathrm{mV}$ and the range of $296.5-330.1 \mathrm{mV}$.

Correlation of ORP with dissolved methane concentrations were strong at $r=-0.588$ and $r=-0.70$, respectively, at the significance level of 0.01 (Table 2).

Background ORP data had an average of $332.9 \mathrm{mV}$ with a standard deviation of 0.53 and the range of $330.8-335.0 \mathrm{mV}$. Distributions of ORP data at steady state and background conditions were significantly different, but the DO distribution with an average of $5.93 \mathrm{mg} / \mathrm{L}$ and standard deviation of 0.09 and the range of $5.55-6.30 \mathrm{mg} / \mathrm{L}$, was not statistically different than background (average $6.05 \mathrm{mg} / \mathrm{L}$, standard deviation of 0.03 , range of 5.93-6.17 $\mathrm{mg} / \mathrm{L}$ ).

The range of parameters, including ORP, DO, $\mathrm{pH}$ and $\mathrm{EC}$, measured during five experiments remained in the range that can be found in surface water and groundwater (Table 2).

\section{Conclusion}

The objective of this study was to assess surrogates for potential contaminants so that changes in water quality 
from the baseline could be detected. It was not an aim of the research to estimate exact methane concentrations in water from the surrogate. Monitoring changes in TDS and methane concentrations of an aquifer is necessary to detect changes in water quality that might be a result of industrial or agricultural activity. Electrical conductivity showed a strong correlation with TDS as well as produced water, fracturing fluid, and the capability to sense increases in small TDS concentrations $(<1 \mathrm{mg} / \mathrm{L})$. With dissolved methane concentrations, general negative correlations were observed in ORP and DO, but other measured parameters, such as $\mathrm{pH}$, and EC, have not shown a general tendency. A strong correlation was consistently observed between dissolved methane concentrations and ORP in all conducted experiments in various ranges of dissolved methane concentrations, while DO had strong correlation with higher methane concentrations in water.

Using a distribution analysis, ORP was effective at resolving changes in dissolved methane levels even when the concentration was as low as $0.30 \mathrm{mg} / \mathrm{L}$. The ability of DO to detect methane concentration changes was acceptable with higher concentrations $\left(>2.5 \mathrm{mg} / \mathrm{L} \mathrm{CH}_{4}\right)$ under conditions where DO is available. Groundwater conditions will vary from these experimental conditions but the data from this study provides a basis for using EC and ORP as surrogates in a real-time monitoring system for potential contamination of groundwater wells.

Open Access This article is distributed under the terms of the Creative Commons Attribution License which permits any use, distribution, and reproduction in any medium, provided the original author(s) and the source are credited.

\section{References}

Analytical Methods Committee of Royal Society Chemistry (1987) Recommendations for the definition, estimation and use of the detection limit. Analyst 112:199-204. doi:10.1039/ an9871200199

Atekwana EA, Atekwana EA, Rowe RS, Werkema DD Jr, Legall FD (2004) The relationship of total dissolved solids measurements to bulk electrical conductivity in an aquifer contaminated with hydrocarbon. J Appl Geophys 56:281-294. doi:10.1016/j. jappgeo.2004.08.003

Darling WG, Gooddy DC (2006) The hydrogeochemistry of methane: evidence from English groundwaters. Chem Geol 229:293-312. doi:10.1016/j.chemgeo.2005.11.003

Eltschlager KK, Hawkins JW, Ehler WC, Baldassare F (2001) Technical measures for the investigation and mitigation of fugitive methane hazards in areas of coal mining. US Department of the Interior, Office of Surface Mining Reclamation and Enforcement, Appalachian Regional Coordinating Center, Pittsburgh, PA, p 124
Floodgate GD, Judd AG (1992) The origins of shallow gas. Cont Shelf Res 12:1145-1156. doi:10.1016/0278-4343

Gorody AW, Baldwin D, Scott C (2005) Dissolved methane in groundwater, San Juan Basin, La Plata County Colorado: analysis of data submitted in response to COGCC orders 112-156 \& 112-157. 12th Annual International Petroleum Environmental Conference, Houston, TX, 8-11 November, 2005

Hayashi M (2004) Temperature-electrical conductivity relation of water for environmental monitoring and geophysical data inversion. Environ Monit Assess 96:119-128. doi:10.1023/B: EMAS.0000031719.83065.68

Ioka S, Sakai T, Igarashi T, Ishijima Y (2011) Long-term continuous in situ potentiometrically measured redox potential in anoxic groundwater with high methane and iron contents. Environ Earth Sci 64:143-149. doi:10.1007/s12665-010-0830-x

Kharaka YK, Thordsen JJ, Conaway CH, Thomas RB (2013) The energy-water nexus: potential groundwater-quality degradation associated with production of shale gas. Proc Earth Planet Sci 7:417-422. doi:10.1016/j.proeps.2013.03.132

Linacre JM (1996) Overlapping normal distributions. Rasch Meas Trans 10:487-488

MacDougall D, Crummett WB et al (1980) Guidelines for data acquisition and data quality evaluation in environmental chemistry. Anal Chem 52:2242-2249. doi:10.1021/ac50064a004

Molofosky LJ, Connor JA, Farhat SK, Wylie AS Jr (2011) Methane in Pennsylvania water wells unrelated to Marcellus shale fracturing. Oil Gas J 109:54-67

Molofosky LJ, Connor JA, Wylie AS Jr, Farhat SK (2013) Evaluation of methane sources in groundwater in Northeastern Pennsylvania. Groundwater 51:333-349. doi:10.1111/gwat.12056

Neff J, Lee K, DeBlois EM (2011) Produced water: overview of composition, fates, and effects. In: Lee K, Neff J (eds) Produced water. Springer, New York, p 3

Osborn SG, Vengosh A, Warner N, Jackson R (2011) Methane contamination of drinking water accompanying gas-well drilling and hydraulic fracturing. PNAS 108:8172-8176. doi:10.1073/ pnas. 1100682108

Rahm D (2011) Regulating hydraulic fracturing in shale gas plays: the case of Texas. Energy Policy 39:2974-2981. doi:10.1016/j. enpol.2011.03.009

USEIA (2012) Annual energy outlook with projections to 2035. Report \#: DOE/EIA-0383

USEPA (1979) EPA methods for the chemical analysis of water and wastes. EPA-600/4-79-020

USEPA (2004) Standard operating procedure: sample preparation and calculations for dissolved gas analysis in water samples using a GC headspace equilibration technique. RSKSOP-175, Revision No. 2

USGS (2006) Methane in West Virginia ground water. Fact Sheet 2006-3011, January 2006

USGS (2012) Dissolved methane in New York groundwater. OpenFile Report 2012-1162, August 2012

Vengosh A, Warner N, Jackson R, Darrah T (2013) The effects of shale gas exploration and hydraulic fracturing on the quality of water resources in the United States. Proc Earth Planet Sci 7:863-866. doi:10.1016/j.proeps.2013.03.213

Vidic RD, Brantley SL, Vandenbossche M, Yoxtheimer D, Abad JD (2013) Impact of shale gas development on regional water quality. Science 340:826. doi:10.1126/science.1235009

Yum K-J, Peirce JJ (1997) Statistical determination of steady state condition in bioremediation tests. Biotechnol Lett 19:763-769. doi:10.1023/A:1018388226090 